\title{
Pengaruh Penggunaan Tepung Onggok Terfermentasi Dengan Trichoderma viride Sebagai Alternatif Pakan Terhadap Konsumsi Pakan dan Pertambahan Bobot Badan Ayam Kampung Super
}

\author{
Anang Widigdyo ${ }^{1}$, Agustina Widyaworo Kunharjati ${ }^{1}$ \\ ${ }^{1}$ Fakultas Peternakan Universitas Islam Balitar \\ Email: anangwidigdyo@yahoo.com
}

\begin{abstract}
Abstrak
Penelitian ini bertujuan untuk mengetahui level penggunaan tepung onggok terfermentasi sebagai pakan alternative pengganti Bekatul dalam meningkatkan penampilan produksi ayam kampung super yang meliputi konsumsi pakan dan pertambahan bobot badan sehingga dapat meningkatkan pendapatan masyarakat dalam usaha peternakan ayam kampung super. Metode yang digunakan dalam penelitian ini adalah metode eksperimen dengan teknik observasi. Rancangan yang digunakan adalah Rancangan Acak Lengkap (RAL) yang terdiri dari 4 perlakuan dan 6 kali ulangan. Perlakuan yang digunakan pada penelitian ini P0 merupakan perlakuan tanpa penambahan Tepung Onggok Terfermentasi (TOT), P1 penambahan tepung onggok sebagai subtitusi bekatul $25 \%$ Tepung Onggok Terfermentasi (TOT) dan $75 \%$ Bekatul dalam ransum untuk mengganti penggunaan Bekatul, P2 penambahan TOT $50 \%+50 \%$ Bekatul dalam ransum, P3penambahan TOT $75 \%+25 \%$ Bekatul dalam ransum. Dalam penelitian ini menggunakan ternak ayam kampung super umur 28 hari sebanyak 120 ekor dan terbagi 5 ekor di setiap ulangan. Kandang yang digunakan adalah kandang koloni dengan ukuran 100 x 70 x $80 \mathrm{~cm}$ di setiap perlakuan dan ulangan. Hasil data penelitian menunjukkan bahwa penggunaan TOT sebagai pengganti bekatul dalam ransum pakan ayam kampung super memberikan pengaruh yang nyata $(\mathrm{P}<0,05)$ terhadap nilai konsumsi pakan ayam kampung super dengan nilai yang paling tinggi pada perlakuan P1 sebesar 143,10 gr/ekor. Hasil data penelitian penggunaan TOT sebagai pengganti bekatul dalam ransum pakan tidak memberikan pengaruh yang nyata terhadap Pertambahan Bobot Badan (PBB) ayam kampung super. Kesimpulan dari penelitian ini adalah penggunaan TOT sebagai subtitusi bekatul dalam ransum pakan tidak memberikan pengaruh negatif terhadap konsumsi pakan dan pertambahan bobot badan ayam kampung super.

Kata Kunci: Tepung onggok terfermentasi, ayam kampung super, penampilan produksi
\end{abstract}

\section{Abstract}

This study aims to determine the level of use of fermented cassava flour as an alternative feed for rice bran in improving the appearance of Ayam Kampung Superproduction which includes feed consumption and body weight gain so as to increase community income in the business of super chicken farming. The method used in this study is an experimental method with observation techniques. The design used was a Completely Randomized Design (CRD) consisting of 4 treatments and 6 replications. The treatment used in this study P0 was treatment without the addition of Tapioca By Product Fermentated (TOT), P1 addition of cassava flour as substitution of $25 \%$ of Fermented Cassava Flour (TOT) and $75 \%$ of bran in ration to replace the use of bran, $\mathrm{P} 2$ the addition of TOT $50 \%+50 \%$ Rice bran in the ration, $\mathrm{P} 3$ addition of $75 \%$ TOT $+25 \%$ Rice bran in the ration. In this research, 120 super-native chickens aged 120 days were divided and 5 chickens were distributed in each test. The cage used was a colony cage with a size of $100 \mathrm{x} 70 \mathrm{x}$ $80 \mathrm{~cm}$ in each treatment and repetition. The results of the research data show that the use of TOT as a substitute for rice bran in Ayam Kampung Superfeed rations has a significant effect $(\mathrm{P}<0.05)$ on the consumption value of Ayam Kampung Super feed with the highest value in the treatment P1 of $143.10 \mathrm{gr} /$ bird. The results of research data on the use of TOT as a substitute for rice bran in feed rations did not have a significant effect on the Increased Weight (PBB) of super native chicken. The conclusion of this study is the use of TOT as a substitute for rice bran in the feed ration does not have a negative effect on feed consumption and body weight gain of Ayam Kampung Super.

Keywords: Tapioca By Product Fermentated, Ayam Kampung Super, production performance 


\section{Jurnal Sains Peternakan}

Volume 7 No. 2, Desember 2019, pp:128-134

ISSN 2579-445

\section{Pendahuluan}

Pakan merupakan biaya produksi yang paling besar dalam usaha peternakan. Untuk menekan biaya produksi pakan tanpa mengurangi produksi ternak unggas yang optimal, maka dapat dilakukan dengan memanfaatkan limbah hasil olahan pertanian yang mempunyai nilai nutrisi cukup sebagai subtitusi bahan pakan ayam kampung super.

Onggok merupakan salah satu limbah hasil olahan pertanian yang dapat digunakan sebagai bahan pakan unggas. Kiramang (2011) menyatakan bahwa penggunaan onggok sebagai bahan pemakaiannya, keran kandungan protein rendah dan serat kasar tinggi sehingga sulit dicerna oleh ternak unggas. Onggok memeliki kandungan energi metabolis sekitar 3000-3500 Kkal/Kg dan kadar protein kasar sebesar 1,6-2,5 \% (Yohanista,dkk, 2014). Purwanti (2012) menyatakan bahwa kandungan nutrisi onggok yaitu kadar abu 1,44\%, protein kasar 3,43\%, serat kasar 5,12 \%, lemak kasar 0,93\%. Berdasarkan data nilai proksimat tersebut menunjukkan bahwa kandungan nutrisi onggok sebagai bahan pakan masih rendah. Untuk meningkatkan nilai protein kasar dan menurunkan kadar serat kasar onggok, perlu dilakukan proses fermentasi.

Fermentasi merupakan salah satu cara untuk meningkatkan mutu onggok, dengan proses terjadinya perombakan dari struktur yang kompleks menjadi struktur sederhana dan mudah dicerna. Pada proses fermentasi diperlukan stater, sebagai perombak. Stater yang digunakan adalah mikrobiotik atau campuran mikrobiotik salah satunya kapang Trichoderma viride. Kapang Trichoderma viride merupakan salah satu jenis mikroba yang mempunyai sifat selulitik sehingga lebih mudah untuk memecah struktur selulosa menjdai senyawa sederhana dan mudah dicerna oleh ternak. Fermentasi onggok menggunakan kapang Trichoderma viride dapat meningkatkan kadar protein kasar dan menurunkan serat kasarnya. Fermentasi onggok dengan Trichoderma viride dapat meningkatkan protein kasar dari 2,8\% menjadi 4,91\% dan menurunkan kadar serat kasar dari $27,5 \%$ menjadi $20,93 \%$ (Zaenuri, 2018).

\section{Materi dan Metode}

\section{Materi Penelitian}

Dalam penelitian ini menggunakan ternak ayam kampung super umur 28 hari sebanyak 120 ekor dan terbagi 5 ekor di setiap ulangan. Kandang yang digunakan adalah kandang koloni bersekat dengan ukuran $100 \times 70$ x $80 \mathrm{~cm}$ di setiap perlakuan dan ulangan. 
Ransum pakan dalam penelitian ini menggunakan bahan pakan jagung, MBM,bungkil kedelai,bekatul, bungkil kelapa, Dicalsium phospat, premix dan tepung onggok terfermentasi.

\section{Pembuatan Tepung Onggok Terfermentasi}

Onggok kering ditambahkan dengan air (kadar air $70 \%$ ), diaduk secara merata kemudian di kukus selama 25 menit denan tujuan untuk mensterilkan bahan. Setelah itu di peram sampai suhu kamar. Kemudian subtrat di inokulasi dengan $4 \%$ dari berat onggok kapang Trichoderma viride, diaduk secara merata dan di peram pada wadah platik secara aerob pada suhu kamar selama 6 hari. Onggok hasil fermentasi di jemur di bawah sinar matahari dengan tujuan untuk menghentikan proses fermentasi. Setelah kering onggok di giling halus selanjutnya dapat digunakan sebagai bahan pakan.

\section{Metode Penelitian}

Metode yang digunakan dalam penelitian ini adalah metode eksperimen dengan teknik observasi. Rancangan yang digunakan adalah Rancangan Acak Lengkap (RAL) yang terdiri dari 4 perlakuan dan 6 kali ulangan. Perlakuan yang digunakan pada penelitian ini P0 merupakan perlakuan tanpa penambahan Tepung Onggok Terfermentasi (TOT), P1 penambahan tepung onggok sebagai subtitusi bekatul $25 \%$ Tepung Onggok Terfermentasi (TOT) dan $75 \%$ Bekatul dalam ransum untuk mengganti penggunaan Bekatul, P2,penambahan TOT $50 \%+50 \%$ Bekatul dalam ransum, P3, penambahan TOT $75 \%+25 \%$ Bekatul dalam ransum.

\section{Variabel Penelitian}

Variabel yang diamati dalam penelitian ini adalah sebagai berikut :

1. Konsumsi Pakan

Konsumsi pakan (g/ekor) adalah jumlah pakan yang diberikan dikurangi dengan sisa pakan dan pakan tercecer dihitung tiap hari selama penelitian dan dinyatakan dalam gram per ekor.

2. Pertambahan Bobot Badan

Pertambahan bobot badan adalah selisih bobot badan akhir dikurangi dengan bobot badan awal di bagi dengan waktu penelitian (rata rata per minggu), dalam satuan gram per ekor. 
Jurnal Sains Peternakan

Volume 7 No. 2, Desember 2019, pp:128-134

ISSN 2579-445

\section{Analisi Data}

Data hasil pengamatan dalam penlitian ini dianalisis menggunakan ANOVA dengan 4 perlakuan dan 6 kali ulangan, jika terdapat perbedaan sangat nyata, dilakukan dengan uji lanjut Duncan.

\section{Hasil dan Pembahasan}

Hasil pengamatan penggunaan Tepung Onggok Terfermentasi (TOT) dengan Trichoderma viridie sebagai subtitusi bahan pakan bekatul dengan variasi konsentrasi P0 tanpa penambahan P1 25\%; P2 50\%;P3 75\% terhadap Konsumsi pakan, Pertambahan Bobot Badan disajikan pada tabel 1.

Tabel 1. Data Hasil Pengamatan Penelitian

\begin{tabular}{ccc}
\hline Perlakuan & Konsumsi Pakan & PBB \\
\hline P0 & $119,14 \pm 12,27$ & $320,00 \pm 31,94$ \\
P1 & $143,10 \pm 3,11$ & $374,17 \pm 70,39$ \\
P2 & $142,45 \pm 4,41$ & $300,83 \pm 35,98$ \\
P3 & $141,64 \pm 7,41$ & $337,50 \pm 42,63$ \\
\hline
\end{tabular}

Sumber : data primer yang diolah 2019

Berdasarkan data di atas menunjukan bahwa pengaruh penggunaan TOT sebagai alternatif pengganti bekatul dalam ransum ayam kampung super dengan komsumsi pakan yang tertinggi dihasilkan pada perlakuan P1 yaitu sebesar 143 gram/ekor, PBB tertinggi dihasilkan pada perlakuan P1 sebesar 374,17 gram/ekor, dan FCR terendah dihasilkan pada perlakuan P0 sebesar 4,17.

\section{Konsumsi Pakan}

Data hasil pengamatan menunjukkan rataan konsumsi pakan dengan satuan gram/ekor mulai yang tertinggi sampai terendah masing masing perlakuan P1 $(143,10)$; P2 (142,45); P3 $(141,64)$; dan P0 $(119,14)$.Kurva rataan konsumsi pakan hasil penelitian ditunjukan pada gambar 1 .

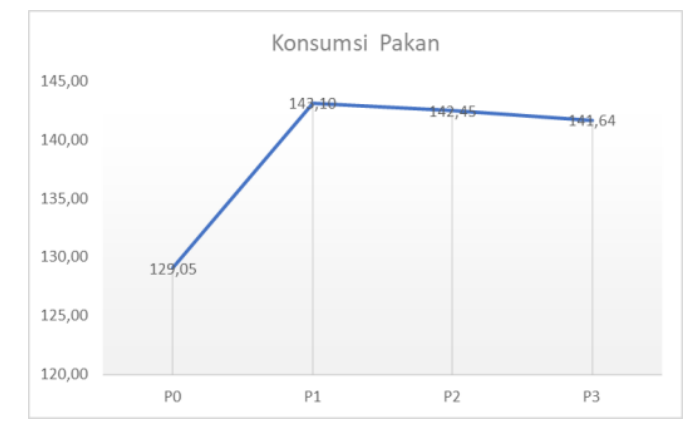

Gambar 1. Kurva Rataan Konsumsi Pakan di Setiap Perlakuan 
Penambahan TOT sebagai pengganti bekatul pada ransum ayam kampung super menunjukkan perbedaan yang nyata $(\mathrm{P}<0,05)$ dengan nilai signifikansi $\mathrm{P}=0,03$. Hal ini menunjukkan bahwa penggunaan TOT sebagai pengganti bekatul memberikan pengaruh yang positif terhadap konsumsi pakan ayam kampung super. Hal ini di tunjukkan dengan hasil data pengamatan konsumsi pakan pada perlakuan P1, P2 dan P3 lebih tinggi dari perlakuan kontrol P0. Proses fermentasi tepung onggok dengan Trichoderma viridie dapat meningkatkan nilai nutrisi pakan dengan memecah polimer karbohidrat menjadi senyawa sederhana sehingga akan mudah dicerna oleh ternak (Sulistiawan, 2015). Trichoderma dapat menghasilkan enzim untuk menghidrolisa karbohidrat kompleks seperti selulosa, hemisulosa dan lignin, sehingga akan meningkatkan nilai kecernaan bahan pakan tersebut (Safari,dkk,2005). Wahyu (2004) menyatakan bahwa besar dan bangsa ayam, temperatur lingkungan,tahap produksi dan energi dalam pakan dapat mempengaruhi konsumsi ransum.

\section{Pertambahan Bobot Badan (PBB)}

Analisis ragam data pengamatan penggunaan TOT sebagai pengganti bekatul dalam ransum pakan ayam kampung super menunjukkan tidak memberikan perbedaan yang nyata $(\mathrm{P}>0,05)$.Pertambahan bobot badan ayam kampung super dari yang tertinggi di tunjukkan pada perlakuan P1 sebesar 374 gram kemudian P3 337 gram; P0 320 gram dan P2 300 gram. Kurva pertambahan bobot badan ayam kampung super hasil penelitian ditunjukkan Gambar 2.

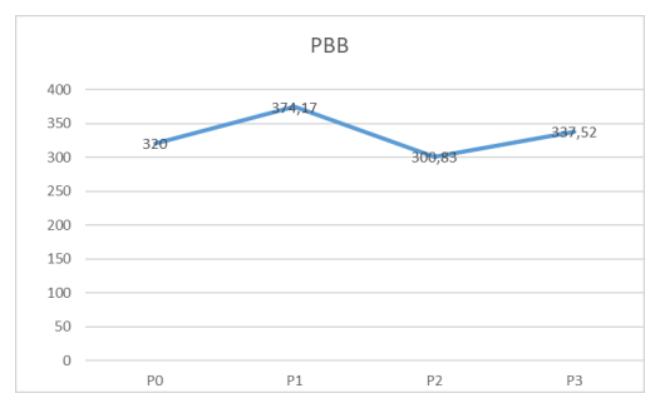

Gambar 2. Kurva Pertambahan Bobot Badan di setiap Perlakuan

Penambahan TOT sebagai subtitusi bekatul pada ransum ayam kampung super tidak menunjukkan perbedaan yang nyata $(\mathrm{P}>0,05)$. Penggunaan TOT tidak memberikan pengaruh yang nyata terhadap PBB ayam kampung super disebabkan karena kandungan protein TOT lebih rendah dibandingkan kandungan protein bekatul, sehingga pertambahan bobot badan ayam selama penelitian kurang maksimal. 


\section{Jurnal Sains Peternakan}

Volume 7 No. 2, Desember 2019, pp:128-134

ISSN 2579-445

Meskipun secara statistika penggunaan TOT sebagai subtitusi bekatul tidak memberikan pengaruh yang nyata, data pengamatan hasil penelitian menunjukkan bahwa pada perlakuan P1 (TOT $25 \%$ + Bekatul $75 \%$ ) menghasilkan rataan PBB tertinggi dibanding perlakuan kontrol (P0) yaitu 374 gram/ekor. Hal tersebut dapat menunjukan bahwa penggunaan TOT sebagai subtitusi bekatul dalam ransum ayam kampung super tidak memberikan pengaruh negatif dan dapat diaplikasikan dalam penyusunan ransum ayam kampung super. Pertambahan Bobot Badan ayam dipengaruhi oleh genetik (strain), jenis kelamin, lingkungan, manajemen pemeliharaan, kualitas dan kuantitas pakan (Umam,dkk, 2014). Penambahan TOT dalam ransum pakan ayam kampung super menunjukkan pertambahan bobot badan pakan pada kelompok perlakuan tidak memberikan pengaruh yang nyata, salah satunya karena karakteristik pertumbuhan ayam kampung yang tidak sebaik pada ayam ras pedaging.

\section{Kesimpulan}

Hasil data penelitian menunjukkan bahwa penggunaan TOT sebagai pengganti bekatul dalam ransum pakan ayam kampung super memberikan pengaruh yang nyata $(\mathrm{P}<0,05)$ terhadap nilai konsumsi pakan ayam kampung super. Hasil data penelitian penggunaan TOT sebagai pengganti bekatul dalam ransum pakan tidak memberikan pengaruh yang nyata terhadap Pertambahan Bobot Badan (PBB) dan konversi ransum pakan (FCR) ayam kampung super.

\section{Daftar Rujukan}

Kiramang,K.2011. Potensi Dan Pemanfaatan Onggok Dalam Ransum Unggas. Jurnal Tekno Sains 5(2):155-163.

Purwanti, F. E. 2012. Kualitas Nutrien Onggok Yang Difermentasi Aspergillus Niger Dengan Penambahan Level Urea dan Zeolit Yang Berbeda. Skripsi: Fakultas Peternakan IPB.

Safari, Sinegani,A. A. G. emtiaz, S. Hajrasullha, and H. Shariatmadani . 2005. Biodegredation of Some Agriculture Residues by Fungi Agirated Submerged Culture Afr. J.Biotech 4(10):1058-1061.

Sulistiawan,I.H.2015.Perbaikan kualitas Ayam Broiler Melalui Fermentasi Dua Tahap Menggunakan Trichoderma resei \& Sacharomices cereviceae. Agripet 15(1):66-71.

Umam,M.H,H.S, Prayogi, V. M. A, Nungiartiningsih. 2014. The Performance Of Broiler System Stage Floor And Double Floor.JIIP 24(3):79-87.

Wahyu, J. 2004. Ilmu Nutrisi Unggas. Edisi ke-4. Universitas Gadja Mada Press. Yogyakarta 
Jurnal Sains Peternakan

Volume 7 No. 2, Desember 2019, pp:128-134

ISSN 2579-445

Yonista,M., O.Sofjan,E., Widodo.2014. Evaluasi Nutrisi Campuran Onggok dan Ampas

Tahu Terfermentasi Aspergilus niger, Rhizopus oligosporus dan Kombinasi Sebagai Pengganti Tepung Jagung.JIIP 24(2):72-83.

Zaenuri,H.2018. Perbedaan Jenis Inokulum terhadap Kandungan Protein Kasar dan Serat Kasar Pada Onggok Terfermentasi. Skripsi: Fakultas Peternakan Universitas Islam Balitar 